\title{
ROMA VE TÜRK HUKUKUNDA MUAYYEN MAL VASIYYETI
}

\author{
Dr. Erkan KÜÇÜKGÜNGÖR*
}

\section{GÍRiş}

Roma Hukukunda, bir kimsenin, bir diğerinin mirasçısı olabilmesi için, bu kimseye mirasçılık sıfatının tanınması, yaní belirli bir sebebe dayanarak mirası iktisap etme yetkisinin o kişiye verilmesi gerekirdi. Kişiye mirasçıllk sıfatının verilmesi de ya vasiyet yoluyla ya da kanunî mirasçulik yoluyla söz konusu olabiliyordu. Eğer muris, vasiyet yapmak suretiyle, bir kimseyi mirasçı tayin etmişse, vasiyete dayanan mirasçlık doğardı. Buna karşılık, muris, herhangi bir vasiyet yapmamışsa, lus Civile'ye göre murisin en yakın agnatik hısmı' olan kişi, hukuken miraş̧ı olurdu ve bu takdirde kanumî ( $a b$ intestato) mirasçllk ortaya çıardi ${ }^{2}$ Imparatorluk Döneminin başlannda, bu miraş̧̧lıklara bir üçüncü mirasçılık eklenmiştir. Buna göre, mevcut bir vasiyet olmasına rağmen, bazı kimselerin bu vasiyette hic dikkate alınmadıklan veya vasiyetten yeterli derecede yararlandırlmadıkları görïlürse, onlara, vasiyet hükümleri hilafına mirasçılık hakkı tanınmaya başlanmıștır. Buna da "vasiyet hilafına kanunî mirasçllık" (contra tabulas miraş̧ıltk), günümìiz deyimleriyle ifade edilecek olursa "mahfuz hisseli mirasçılı" adı verilmiştir $^{3}$.

Roma Hukukunda, vasiyete dayanan mirasçılık kural, kanunî mirasçılkk ise istisnaydı. Muayyen mal vasiyetlerinin büyük bir bö-

* A.U. Hukuk Fakültesi Roma Özel Hukuku Anabiłim Dalı.

1. Aynı ev (domus) içinde yaşayan ve ortak ata hayatta olsaydu yaşayacak olan kimseleri birbirine bayłayan fus Civile hismlığna agnatio bisiniliğ denir (BERGER, s. 358; KARADENIZ-CELEBICAN, s. 159).

2. DI MARZO, s. 503; UMUR, Miras, s. 162.

3. HONG, s. 392 vd.; SCHULZ, s. 266 vd.; UMUR, Miras, s. 185 vd. Türk Hukukunda "mahfuz hisseli mirasçlar", MK 452/'de tohdid olarak saynlmuşur. Mirasbirakan, bu maddede sayılan mahfuz hisseli mirasçlann mahfuz hisseleri (MK 453) d!sunda kafan tereke ìzexinde veya mahfuz hisseli mirasçı yołssa terekenin tamamu üzerinde tasarrufta bulunabilir (MK 452/1). 
lümü de, vasiyet içinde yapılan tasarruflardan oluşuyordu. Bu nedenle, Roma Hukukundaki muayyen mal vasiyeti ve bunun özellikleri ele alınmadan önce, vasiyete dayanan mirasçılığın Roma Hukukundaki durumunun ve niteliklerinin incelenmesi gerekmektedir. Bu amaçla, çalışmamızda, öncelikle Roma'da vasiyete dayanan mirasçılık ele alınacak, daha sonra muayyen mal vasiyeti, Türk Hukuku ile söz konusu olabilecek ilişkiler de dikkate alınarak, özellikle benzer yönleriyle ortaya konmaya çalışılacaktır.

\section{ÇILIK}

1. ROMA HUKUKUNDA VASIYETE DAYANAN MIRAS-

\section{A. Genel Olarak}

Roma Miras Hukukunda kabul edilmiş olan en önemli ilke, vasiyete dayanan mirasçılık mevcut olduğu sürece, kanunî mirasçılığa başvurulamamasıdır. Roma'da kanunî mirasçılık, ancak ölen kişinin bir vasiyeti bulunmadığı, yaptığı vasiyet geçersiz olduğu veya nasbettiği mjrasçılar mirasçı olmadığı ya da olamadığı takdirde sözkonusu olabilirdi. Zira, Roma'da, ailenin halefini belirleme hakkı öncelikle aile babasına, bu mümkün olmadığı takdirde hukuk düzenine düşen bir hak olarak nitelendirilirdi ${ }^{4}$. Aile babasının bu hakkı, XII Levha Kanunu'nda da belirtilmekteydi: uti legassit pater familias super pecunio tutulave suae rei ita ius esto (Aile babas?nın, mallari hakkındaki son arzusu, kanun hükmüne sahip olsun) ${ }^{5}$. Ancak, Roma'nın ilk dönemlerinde, bunun tam tersi olduğu anlaşılmaktadır. Zira, ilk dönemlerde, aile babasının ölümüi ile sui iuris hale gelen kişiler, doğrudan doğruya ona halef olmakta ve hatta mirasçılık sıfatı sadece bu kimselere tanınmaktaydı. Bu da ilk dönemlerde, öncelik taşıyan mirasçılığın kanunî mirasçılık olduğunu, yani mirasın aile babası tarafından değil hukuk dïzeni tarafından düzenlendiğini göstermektedir. Vasiyet yapma yaygınlaştıktan ve çeşitli vasiyet şekilleri ortaya çıktıktan sonra ise, kanunî mirasçılık, vasiyete dayanan mirasçılığın gerisinde kalmış ve sadece geçerli bir vasiyetin bulunmadığ hallerde uygulanabilmeye başlamıştır ${ }^{6}$.

4. HONIG, s. 383; BERK\}, Roma Miras, s. 550; DI MARZO, s. 540; KOSCHAKERAYTTER, s. 373 .

5. HONIG. s. 362. Türk Hukukunda ise, kanunî miraş̧ı̆ığın esas mirasçılık şekli olduğu, iradî mirasçuığın ise tâli bir nitelik taşıdığı, doktrinde genel olarak kabul edilmektedir (IMRE-ERMAN, s. 5; INAN, Miras, s. 23-24). Ancak, iradî mirasçılığın, esas mirasçılık tipini teşkil ettiğini savunan yazarlar da vardır (ÇAGA, s. 59-60).

6. KOSCHAKER-AYTTER, s, 373; DI MARZO, s. 540; UMUR, Miras, s. 181-182. 
Bütün bunlann yanında, Roma Hukukunda, vasiyete dayanan mirasçılık ile kanunî ( $a b$ intestato) mirasçılık birarada bulunamazdı (Nemo pro parte testatus, pro parte intestatus decedere potest $=\mathrm{Hiç}$ kimse kısmen vasiyette bulunmuş, kısmen vasiyetsiz olarak vefat edemez) ${ }^{7}$. Modern hukuk sistemlerinde kabul edilmeyen bu prensibe göre, bir kimse, terekesinin bir bölümünü kanunî ( $a b$ intestato) mirasa terketmek niyetiyle, diğer bölümü için bir mirasçı nasbettiği takdirde, nasbedilen o mirasçı, terekenin tamamı için mirasçı olur, kanunî mirasçılık dikkate alınmazdı .

\section{B. Testamentum (Vasiyet veya Vasiyetname) Kavramı}

Latince'de testamentum kelimesi yerine göre, vasiyet veya vasiyetname anlamına gelmektedir. Ulpianus, testamentum'u şu şekilde tanımlamaktadir: Testamentum est mentis nostrae iusta contestatio, in id sollemniter facta, ut post mortem nostram valeat (Testamentum, ölümümüzden sonra geçerli olması için, irademizin şeklen tespit edilmiş bir ifadesidir) (Ulpianus. 20. 1) ${ }^{9}$.

Roma Hukukunda vasiyet, kişinin son iradesini ortaya koyan, şekle bağlı, tek taraflı bir hukukî işlem olarak kabul ediliyordu. Roma Hukuku, Germen Hukukunda ortaya çıkıp günümüz hukukunda da kabul edilen ve bir akit niteliğinde olan miras mukavelesini tanımıyordu ${ }^{10}$.

Vasiyet, ölüme bağlı bir hukukî işlem olduğu için, ölüm anına kadar vasiyetçi tarafından değiştirilebilirdi. Yapılması şekle bağlı bir işlem olan vasiyetten dönme de önceleri belirli şekillere bağlanmıștı. Ancak, M.S. 2. yy.'dan itibaren, vasiyetten dönmeye iliş̧kin şekilcilik ortadan kalkmış ve dönme iradesini gösteren her hareketin, vasiyetten dönmek için yeterli olacağı kabul edilmeye başlanmiştır ${ }^{11}$.

7. KOSCHAKER-AYTTER, s. 349; MURREAD, s. 206-207; HONIG, s. 363 ; SCHULZ, s. 253 vd.

8. DI MARZO, s. 504; HONIG, s. 363; UMUR, Miras, s. 162.

9. DI MARZO, s. 512; SCHULZ, s. 239.

10. KOSCHAKER-AYTTER, s. 359; DI MARZO, s. 504-505. Miras mukavelesi, Türk Hukukunda kabul edilmiş ve MK 474 vd. ile 492 vd. maddelerinde hükme bağlan* muşttr.

11. UMUR, Miras, s. 167. Türk ve Isviçre hukuklarında da, vasiyetten rilicu konusunda, vasiyette bulunan kişiye tam bir serbestâ tanındığı görülmektedir. Vasiyet yapan kişinin bu yetkisinden önceden feragat etmesi hükkimsüzdür (TUOR, s. 381; ÖZTRAK, s. 46; BERKI, Miras, s. 81; KÖPRULUல, s. 126). 
Roma Miras Hukukunun en önemli özelliklerinden biri, vasiyetin ana fonksiyonunun mirasçı nasbı oldugunun kabul edilmesidir. Vasiyette yer alan diger işlemler, yani vasi tayinleri, köle azad etmeleri gibi tasarruflar arasında mirasçı nasbı, vasiyetin ağırlık merkezini oluştururdu. Vasiyette mirasçı nasbedilmemişse veya nasbedilmiş olmasına rağmen herhangi bir sebeple mirasçı nasbı tasarrufu geçersiz ise, vasiyetin diğer hükümleri de geçersiz olurdu. Buna karşılık, vasiyetteki bütün hükümler geçersiz, yalnızca mirasçı nasbına iliş̧in tasarruf geçerli ise, vasiyetin o hükmï ile geçerli olduğ kabul edilirdi. Gaius bu durumu, "mirasçı nasbı, her vasiyetin başı ve temeli addedilir", şeklinde ifade etmiştir (Gaius, Institutiones. 2. 229): Iustinianus Dönemi'nde ise ${ }^{12}$, mirasçı nasbının da diğer tasartuflarla eşdeğerde olduğu kabul edilmeye başlanmış ve birçok olayda vasiyetteki mirasçı nasbına ilişkin tasarruf geçersiz olduğu halde, diğer hükümlerin geçerli olduğu sonucuna vanlmış$\mathrm{tir}^{13}$.

Roma Hukuku'nda vasiyet, mamelekin bütününe ilişkin bir tasarruf olarak kabul edildiği için, muris sadece tek bir vasiyet ile mirasçı tayin edebilirdi. Bundan dolayı, ikinci bir vasiyetin yapılması, birinci vasiyetin bütünüyle ortadan kaldırıldı̆̆ı anlamına gelirdi. Hatta, birinci vasiyetin, ikinci vasiyetle çelişmeyen hükümleri dahi ortadan kalkmış olurdu ${ }^{14}$.

\section{Vasiyet Yapma Ehliyeti ve Mirasçllı Ehliyeti}

Vasiyet yapan kimsenin, vasiyeti yaptı̌̆ anda, vasiyet yapma ehliyetine (testamenti factio activa) sahip olması gerekirdi. Bunun için de Roma vatandaşı olmalı ve fiil ehliyetine sahip bulunmalıydı. Roma'da mirasın amacı, ailenin (familia) idaresi için bir halef tayin etmek oldugundan, vasiyet yapan kişinin aile babası (pater familias) olması şarttı. Bu nedenle, aile evlâdı, aile babasının nzası olsa dahi, vasiyet yapamazdı. Aynı şekilde, reşit olmayan kişilerin, ya-

12. IUSTINIANUS, Institutiones. 2.20. 34.

13. KOSCHAKER-AYITER, s. 360; UMUR, Miras, s. 167; OĞUZOĞLU, s. 293; DI MARZO, s. 513. Roma.Hukukundaki bu şekilcilik ve mirasçı nasbs konusundaki mutlaklık, Türk hukukunda kabul edilmemiş, MK 461 vd.'da bu konuda geniş bir hareket serbestisi tanınmışır.

14. KOSCHAKER-AYITER, s. 359-360; SCHULZ, s. 252-253; UMUR, Miras, s. 167. Buna karşılık, Tüirk Hukukunda, MK $491^{\prime} \mathrm{e}$ göre, sonraki tarihli vasiyet, önceki tarihli vasiyetten açıkça dönüldü̉günü göstermiyorsa, sonraki tarihli vasiyetteki hǘkümlerden öncekini açıkça tamamlayıcı olmayanłari, önceki vasiyetin yerine geçer. Yani, önceki tarihli vasiyetin, sonraki tarihli vasiyet ile çelişmeyen hükulımleri geçerli olarak kalır. 
bancıların, müebbet kürek veya idam mahkumlarının ve müsriflerin de vasiyet yapma ehliyetleri yoktu ${ }^{15}$. Roma Hukukunun ilk dönemlerinde, kadınların vasiyet yapma ehliyetine sahip olmadılan dikkat çeken bir husustur. Sonraki dönemlerde ise, kadınların, vasilerinin izniyle vasiyet yapabilmeye başladıklan görülmektedir ${ }^{16}$. Bunun yanında, Augustus, aile evlatlarna, peculium castrense ${ }^{17}$ üzerinde vasiyet yapabilme yetkisi tanımış, Iustinianus ise bu yetkiyi peculium quasi castrense ${ }^{181}$ yi de kapsayacak şekilde genişletmiştir $^{\text {19. }}$.

Vasiyet yapan kimsenin, vasiyet yapabilme ehliyetine (testamenti factio activa) sahịp olması gerektiği gibi, mirasçının da mirasçılık ehliyetine (testamenti factio passiva) sahip olması gerekirdi. Türk Medeni Kanunu'ndaki genellik ve essitlik ilkelerine dayanan hak ehliyetinin bir sonucu olan mirasçllk ehliyetinden farklı olan bu ehliyete göre, Klasik Dönem sonuna kadar Roma vatandaşı olmayanlarla tüzel kişilerin, son dönem' Roma Hukukunda ise dinsizlerin ve dinden dönenlerin mirasçılık ehliyetine sahip olmadıkları kabul ediliyordu ${ }^{20}$. Aynı şekilde, müebbet cezalara veya ölüm cezasına mahkum edilmiş kimseler de mirasçı olamazlardi1 Bazı özel durumlarda da, mirasın düssmesini veya iktisabını olanaksız kılan sebeplẹ ortaya çıkıyordu. Örneğin, Augustus döneminde, bekârlarla çocuksuz evliler, daha sonraları, vasiyetçiyi öldüren veya vasiyette bulunmasına engel olan kimseler, mirasçıllk hakkından yoksun bırakılırlardı ${ }^{22}$. Buna karşılık, başkasının kölesini veya bir aile evlâdını mirasçı nasbetmek mümkündü. Bu takdirde bunlar, mirası, hakimiyeti altında bulundukları aile babasının muvafakatıyla ve onların menfaatine iktisap etmiş olurlardi ${ }^{23}$.

15. DI MARZO, s. 502-503; KOSCHAKER-AYITER, s. 348; UMUR, Miras, s. 161162.

16. KOSCHAKER-AYTTER, s. 360-361; DI MARZO, s. 514; BERKI, Roma Miras, s. 546-547.

17. Asker olan aile evladının, savaşta elde etmis olduğu mallardan olusan peculium (UMUR, Lügat, s. 154; AYTTER, s. 59-60; BERKI, Roma, s. 146-147).

18. Constantinus'un, MS. 326 yllında, sarayındaki aile evladi durumunda olan memurlann maaşarnndan artırdiklan veya imparatordan ihsan olarak aldikları paradan olușan peculium'u da peculium castrense olarak kabul etmesiyle ortaya çıkan peculium (UMUR, Lügat, s. 154; A YITER, s.60; BERKİ, Roma. s. 147).

19. DI MARZO, s. 515-516; UMUR, Miras; s. 169. Türk Hukukunda ise, MK 449'a göre, 15 yașmt bitiren ve temyiz kudretime sahip olan kişi, vasiyet yapabilme ehliyetine sahiptir.

20. DI MARZO, s. 505; UMUR, Miras, s. 162.

21. DI MARZO, s. 505; UMUR, Miras, s. 162 .

22. HONIG, s.26-27; UMUR, Miras, s. 171; DI MARZO, s. 516-517.

23. DI MARZO, s. 505; KARADENIZCELEBICAN, s. 170; UMÜ, Miras, s. 162. 163. 


\section{Vasiyet Çeşitleri}

Roma Hukukunda, farklı dönemlerde, birbirinden oldukça farklı vasiyet çeşitlerinin ortaya çıktığı ve bunlara geçerlik tanındığ görülmektedir ${ }^{24}$.

Gaius, eski dönemlerde iki çeşit vasiyet şeklinden sözetmektedir. Bunların birincisi, "harbe hazır ordu huzurunda" anlamına gelen testamentum in procinctu'dur. Bu çeşit vasiyeti, askerler, komutan savaşa karar verdikten sonra, birbirleri önünde, sözlü olarak ve hiçbir şekle uymak zorunda kalmaksızın son iradelerini beyan etmek suretiyle yaparlardı ${ }^{25}$. Gaius'un sözünü ettiği ikinci vasiyet şekli ise comitia' lar huzurunda yapılan vasiyet (testamentum calatis comitiis)'tir. Savaş olmadı̆̆ dönemlerde yapılan ve genel vasiyet şekli olan bu vasiyet, yılda iki kez (24 Mart ve 24 Mayıs) tekrarlanan törenler sırasında yapılırdı. Halk meclisleri, rahiplerin de katılmasıyla toplanır, vasiyet yapan kişinin iradesi rahipler tarafından kabul edildjkten sonra, halk meclislerinin onayına sunulurdu. Meclislerin vasiyeti kabul usulü hakkında kaynaklarda açık bilgi olmamasına rağmen, meclislerin sadece tanłk fonksiyonu gördükleri kabul edilmektedir ${ }^{26}$. Gaius'un sözünü ettiği bu iki çeşit vasiyet şekli de sadece Roma vatandaşları tarafından yapılabilirdi ${ }^{27}$.

Cumhuriyet Döneminin sonlanndan itibaren, bu vasiyet şekillerinden her ikisi de uygulamadan kalkmaya başlamıştır. Zira, savaş sırasında yapılan vasiyetname istisnaî, diğeri ise yılda iki kez, belirli günlerde yapılması mümkün olan vasiyet şekilleri idi. Bu tür sınırlamalarla bağlı olmaksızın, her zaman vasiyet yapabilme olanağını sağlamak amacıyla hukukçular karışık bir usul bulmuşlar ve bu usul, yeni vasiyet şekillerinin temelini oluşturmuştur.

Testamentum per aes et libram adını taşıyan bu usul, comitia'ların toplanmasını bekleyemeyecek kadar hasta veya ölümünü yakın gören kimselerin, istisnaî olarak başvurduklan bir usul olarak

24. Ttirk Hukukunda, MK 478 gereğince, üç vasiyet şekli kabul edilmiştir. Buna göre, vasiyet, "resmi vasiyet", "elyazısı ile vasiyet" ve "sözłí vasiyet" olmak üzere üç şekilde yaplabilir.

25. HONIG, s. 375; KASER, s. 290; OGUZOĞLU, s. 294; DI MARZO, s. 518-519; BERGER, s. 733; UMUR, Lïgat, s. 209; SCHULZ, s. 240.

26. UMUR, Miras, s. 169: BERKİ, Roma Miras, s.543-544; MUIRHEAD, s. 204; SCHULZ, s. 240-241.

27. OGUZOGLU, s. 294. 
ortaya çıkmıştı. Bu usul, mancipatio familiae işlemine dayanıyordu. Yani, aile mameleki, güvenilir bir kimseye (emptor familiae), gizli bir semen karşılığında mancipatio ${ }^{28}$ ile devrediliyordu. Vasiyet yapan kişi, mameleki alan kişiye son arzulannı bildirir, mallanı alan kişi ise bu arzulan yerine getirmeyi taahhüt ederdi ${ }^{29}$.

Oldukça zor ve karışık şekil şartlarını gerektiren mancipatio işleminin bu karmaşık şartlarına taraflar, zamanla hiç veya gereği gibi uymamaya başlayınca praetor, mancipatio işlemini salt bir formalite haline getiren bir takım tedbirler aldı. Böylece praetor, M.Ö. 2. yy.'dan itibaren, yedi tanı̆̊n mührünü taşıyan bir vasiyetnameyi ibraz eden kimseye, Ius Civile'nin şekilciliğini temsil eden mancipatio işleminin yapılmış olup olmadı̆̆ını araştırmadan, bonorum possessio secundum tabulas (vasiyetnameye uygun bonorum pos sessio)'1 bahşedeceğini beyan etti. Bu suretle, praetor vasiyeti denilen ve sadece yedi tanı̆ı̆ı huzurunda düzenlenen vasiyet şekli doğmuş oldu ${ }^{30}$.

Iustinianus Hukukunda ise, sözlü ve yazılı olmak üzere iki vasiyet şekli daha ortaya çıkmıştır. Sözlü vaziyet (testamentum per nuncupationem), yedi tanığın önüinde son arzuların bu tanklara bildirilmesinden ibaret olan ve şekle tâbi olmayan bir vasiyet şekliydi. Yazılı vasiyet (testamentum per scripturam) ise, yedi reşit Roma vatandaşı tanığın ve vasiyeti yapacak kişinin, vasiyetnameyi birlikte imzalamalanyla yapılırdı. Vasiyeti yapacak olan kişi yazı yazmasını bilmiyorsa, onun yerine sekizinci bir tank vasiyetnameyi imzalardı. Yazılı vasiyette, tanık bulunması zorunluluğu ve işlemin bir bütün teskil etmesi Ius Civile'den, imza eden tantkların sayısı ise praetor hukukundan kaynaklanmaktadir ${ }^{3 !}$.

Iustinianus Hukukunda, bu yazılı ve sözlü vasiyet şekilleri yanmda, yargı organları veya şehir memurları huzurunda yapilan resmî vasiyetler de mevcuttu ${ }^{32}$.

28. Mancipatio işlemi hakkındia ayrmtılı bilgi için; Bak. UMUR, Eşya, s. 68 vd.

29. HONIG, s. 376; KASER, s.290-291; MUIRHEAD, s. 205; OGUZOGLU, s. 295296; BUCKLAND-MC NAIR, s. 134; SCHULZ, s. 241 vd.

30. UMUR, Miras, s.169-170; OGUZZOGLU, s. 296; BERKI, Roma Miras, s. 545; SCHULZ, s.245-246.

31. DI MARZO, s.522-523; OĞUZOĞLU, s. 296; UMUR, Miras, s. 170; BERKI, Roma Miras, s. 545; BERGER, s. 734.

32. DI MARZO, s. 523; UMUR, Miras, s. 170. 
Ayrıca, istisnaî nitelik taşıyan bazı vasiyet şekilleri de vardı. Ömeğin, Iulius Caesar, geçici bir süre için, askerlerinin, istedikleri şekilde vasiyet yapabilmelerine izin vermiştir. Bu çeşit izinler, $\mathrm{Ca}$ esar'dan sonra diğer imparatorlar tarafından da yine geçici olarak verilmiştir. İmparator Traianus ise, askerlerin istedikleri şekilde vasiyet yapabilmeleri imtiyazını süresiz olarak kabul etmiştir. Asker vasiyeti (testamentum militis) denilen bu vasiyet şeklinde, diğer vasiyetler için gerekli olan belli sayıdaki tanığa ihtiyaç olmaksızın, sadece iradenin açık bir şekilde ortaya konmuş olması yeterliydi. $\mathrm{Bu}$ çeşit vasiyetler, askerlerin terhisinden itibaren bir yll sonra geçerliliklerini kaybederlerdi ${ }^{33}$.

\section{E. Vasiyetin Konusu}

\section{Mirasçı Nasbı}

Bir vasiyetin'geçerli olabilmesi için, yukarıda sözü edilen şekil şartlarının yanında, geçerli bir mirasçı nasbının da bulunması gerekirdi. Klasik Hukuk Dönemi'nin sonlanna kadar, vasiyetin ilk hükmünün daima miraş̧ı nasbı olması gerektiği kabul edilmiști. Mirasçı nasbından önce yapılmış tasarruflar geçerli olmazlardı. Miraş̧ı nasbetmeden önce yapılmış olan her tasarrufun geçersizliğine işaret eden Gaius, "vasiyetler kuvvetlerini mirasçı nasbından alırlar" (testamenta vim ex institutione heredis accipiunt) demekteydi ${ }^{34}$. Bunun yanında, mirasçı, Latince, emredici ve belli sözlerle nasbedilebilirdi. Örneğin, "Titius heres esto" (Titius mirasçı olsun) veya "Titium heredem esse iubeo" (Titius' un mirasçı olmasını uygun görïyorum) gibi ibarelerin kullanılması gerekiyordu. Constantinus'tan itibaren ve Iustinianus Dönèmi'nde bu çeşit şekilcilikler ve Latince kullanılması zorunluluğu ortadan kalkmıştır ${ }^{35}$.

Vasiyette mirasçı nasbedilen kişinin kim olduğunun açık şekilde anlaşılabilmesi gerekirdi. Vasiyeti yapan kişi, hataen, arzu ettiği

33. DI MARZO, s.523-524; KASER, s. 291; UMUR, Miras, s. 170-171; HONIG, s.378-379; BERGER, s.734; SCHULZ, s.244-245.

34. DI MARZO, s. 526 .

35. HONIG, s. 380; MUIRHEAD, s. 206; DI MARZO, s. 527; BERKI, Roma Miras, s. 547-548; GÜNAL, s. 435. Türk Hukukunda, ölüme bağlı tasarrufun mirasçı nasbı oldugunu belirten açık ve belirli kelime ve deyimlerin kullanulmasına gerek yoktur. MK 463'e göre, terekenin tamamınn veya bir kısmunın bir kişiye veya kişilere intikalini miras birakanın arzu ettiŏini belirten her kelime, her deyim onun kişiyi mirasçı nasbettiğine bir karine kabul edilir. (INAN, Miras, s. 153; ŞENER, s. 10; GÜRSOY, s. 35; BELGESAY, s. 51; OOUZMAN, s. 168-169; GONENSAY-BIRSEN, s. 131). 
kimseden başkasını miraş̧ı göstermişse, bu miraş̧ı nasbı geçerli olmazdi ${ }^{36}$.

Vasiyeti yapan kişi, mirasçı nasbedilecek kişinin belirlenmesini başka bir kimsenin iradesine bırakamazd, bunu bizzat kendisi yapmak zorundaydi ${ }^{37}$.

Mirasçı nasbına ilişkin bir diğer önemli husus ise, mamelekin bir kısmı için mirasçı nasbının geçerli olmayacă̆ı, mirasçı nasbının, mamelekin bütününe ilişkin olması gerektiğidir ${ }^{38}$.

Taliki şarta bağlı mirasçı nasbı mümkün olduğu halde, infisahi şarta bağlı mirasçılık mümkün değildi. Bu tür şartlar yok sayılır ve vasiyetin mirasçı nasbına ilişkin hükmü geçerli olarak kalırdı. Buna bağlı olarak, mirasçı nasbedilen kişinin, belli bir şart gerçekleştiğinde, mirasçı olmaktan çıkmasına veya mirasçı nasbedilen kişinin, ölümünde mirası belirli bir kişiye bırakmasına illişkin şartlar yok sayılır ve mirasçı nasbı geçerliliğini korurdu ${ }^{39}$. Zira, Roma Hukukunda, semel heres semper heres, yani, "bir defa mirasçı olan daima mirasçı kalır" kuralı geçerli idi ${ }^{40}$.

Vasiyet yapan kişi, bir tek miraş̧ı nasbedebileceği gibi, birkaç kişiyi birlikte de mirasçı nasbedebilirdi. Bu birkaç mirasçıdan birisi vasiyeti yapan kişiden önce ölür, ehliyetsizlige düşer veya feragat edecek olursa, onun payı, diğer pay sahiplerine eşit şekilde dağıtılirdi'.

\section{Muayyen Mal Vasiyetleri}

Bir vasiyette mutlaka bulunması gereken mirasçı nasbına ilişkin tasarrufun yanında, vasiyet, diğer bazı tasarrufları da içerebilirdi. Bu tasarruflar da vasi tayinleri, köle azad etmeleri ve özellikle

36. DI MARZO, s. 528; UMUR, Miras, s. 171.

37. DI MARZO, s. 528; UMUR, Miras, s. 172.

38. BERKI, Roma Miras, s. 548. Türk Hukukunda ise, MK $463^{\circ}$ e göre, mirasçı nasbı, terekenin tamamına veya bir kısmına ilişkin olabilir.

39. Bu selilci kuralı pratik bakımdan etkisjz hale getiren fideicommissum'ların ozzellikleri, aşağıda aynuntılı olarak ele alınacaktır.

40. KOSCHAKER-AYITER, s. 368; MUIRHEAD, s. 206; HONIG, s. 380; DI MARZO, s. 526; BUCKLAND-MC NAIR, s. 126; SCHULZ, s. 261-262. TUnk Hukukunda ise, MK 468 vd.'dar fevkalade ikame hatkme baglanarak, Romadaki bu esas kabul edilmemiştir.

41. HONIG, s. 381; DI MARZO, s. 530; UMUR, Miras, s. 172; BERKI, Roma Miras, s. 548; GONAI, s. 436. 
muayyen mal vasiyetleri şeklinde olabilirdi. Roma Hukukunda, vasiyet yapan kişi, yaptığı muayyen mal vasiyetleriyle, mirasçısı aleyhine olmak üzere, bir kimseye belirli mallarını iktisap etme imkanını tanırdı. Roma'da üç çeşit muayyen mal vasiyeti sözkonusuydu. Bunlar, legatum, fideicommissum ve praelegatum idi. Muayyen mal vasiyetleri, aşağıda ayrıntılı olarak inceleneceğinden, burada üzerinde durulmayacaktır.

\section{F. İkameler (Substitutio)}

Vasiyette bulunan kişi, taliki bir şarta bağlı olarak, bir kimseyi miraş̧ı nasbedebilirdi. Bu çeşit mirasçı nasbetme hallerinin en önemli örneğini ikame (substitutio)'ler oluşturmaktaydı ${ }^{42}$. Roma Hukukunda iki çeşit ikame vardı. Bunlar, alelade ikame (substitutio vulgaris) ve küçü̈klere ilişkin ikame (substitutio pupillaris) idi.

\section{Alelade Ikame (Substitutio Vulgaris)}

Alelade ikamede, vasiyeti yapan kişi, ilk nasbolunan mirasçını mirası iktisap etmemesi (örneğin mirası reddetmesi) veya edememesi (örneģin muristen önce ölmesi) ihtimalleri için yedek bir mirasçı tayin etmektedir. Burada, ikinci miraş̧ı (substitutus= ikame olunan, yedek mirasçı), birinci mirasçının (institutus = mansup, ön mirasçı) mirasçı olmaması geciktirici şartıyla, mirasçı nasbedilmiş olmaktadır ${ }^{43}$. Bu çeşit mirasçılardan arka arkaya birden fazla kişinin gösterilmesi de mümkündüü

\section{Küçüklere İlişkin İkame (Substitutio Pupillaris)}

Bu çeşit ikamede, vasiyeti yapan aile babası, henüz reşit oimamış oğlu için bir yedek mirasçı ikame ederdi. Bunu da sadece, oğlunun miraş̧ı olamaması halini düşünerek değil, aynı zamanda, reşit olmadan ölmesi ihtimalini de düşünerek yapardi ${ }^{45}$. Yani, bu durumda, aile babası, kendisine mirasçı olamayacak olan oğluna ikamede bulunmasının yanında, reşit olmadan ölen çocuğunun mirasçısını da bizzat tayin etmiş olmaktaydı. Bunun sebebi, reşit olmayan küçïuğün, vasinin izniyle dahi olsa, vasiyet yapma imkanının

42. Türk Hukukunda ise, ikameli ölïme bağhı tasamuflar, hem mirasçı nasbında hem de muayyen mal vasiyetinde sözkonusu olabilmektedir.

43. BERGER, s. 721; HONIG, s. 381; KOSCHAKER-AYITER, s. 370; DI MARZO, s. 532.533.

Alelade ikame, Türk Medeni Kanunu'nun 467'inci maddesinde, Roma Hukukundaki duruma benzer şekilde dïzenlenmiştir.

44. DI MARZO, s. 533; UMUR, Miras, s. 172; SCHULZ, s. 260-261.

45. MUIRHEAD, s. 206; BERGER, s. 721-722; HONIG, s. 381 ; \$CHULZ, s. 262 vd. 
olmamasıdır. Bu nedenle, onun vasiyetini de adeta babasi yapmaktadir $^{46}$.

Küçüğe yedek mirasçı ikame edilmesi halinde, küçügün mamelekinde, babanın ölümüiyle kendi ölümü arasındaki dönemde herhangi bir şekilde bir artma meydana gelebilirdi. Romalı hukukçular, babanın ölümünden sonra, küçüüün mamelekinde meydana gelen bu artışın da mameleke dahil olduğunu kabul ederek, bunun yedek mirasçıya intikal edeceği sonucuna varmişlardır ${ }^{47}$.

Iustinianus Döneminde, substitutio pupillaris, akıl hastası füruları da kapsayacak şekilde genişletilmiş ve Ortaçağ hukukçuları buna substitutio quasi pupillaris (kïçüklere ilişkin ikame benzeri) adını vermişlerdir ${ }^{48}$.

\section{ROMA HUKUKUNDA MUAYYEN MAL VASİYETİ}

\section{A. Genel Olarak}

Roma'da, yukanda da değinildiği gibi, bir vasiyetin geçerli olabilmesi için, mutlaka mirasçı nasbma îlişkin bir hükmü içermesi gerekiyordu. Geçerli bir mirasçı nasbını içeren vasiyette, diğer bir takım tasarruflar da bulunabilirdi. Bu tasarruflar da, murisin ölümünden sonra dul kalacak olan karısı veya reşit olmamıs çocukları için vasi tayinleri, köle azad etmeleri ve özellikle muayyen mal vasiyetleri şeklinde olabilirdi.

Muayyen mal vasiyeti, mirasçı nasbından farklıdır. Mirasçı nasbı, küllî halefiyet sonucunu dogurur ve bu nedenle mirasçı nasbedilen kişi, murisin borçlarından da sorumludur. Oysa, muayyen mal vasiyetinde cüz'î halefiyet doğar ve lehine muayyen mal vasiyet edilen kişi, murisin borçlanndan sorumlu olmaz ${ }^{49}$.

46. KOSCHAKER-AYTTER, s. 370-371; DI MARZO, s. 534-535; BERKI, Roma Miras, s. 549.

47. KOSCHAKER-AYITER, s. 371; UMUR, Miras, s. 173.

48. KOSCHAKER-AYITER, s. 370; DI MARZO, s. 535-536; BERGER, s. 722; SCHULZ, s. 265.

49. KOSCHAKER-AYITER, s. 404; UMUR, Miras, s. 174. Türk doktrininde de, muayyen mal vasiyetiyle mirasçı nasbı arasındaki farklar üzerinde durulmakta ve sözü edilen farka, mansup mirasçının mirasın açıldığı andan itibaren tereke izzerinde bit aynî hakka sahip olmasına karşın, lehine muayyen mat vasiyet edilen kişinin, vasiyeti ifa ile mïkellef olanlara karşı, sadece malın kendisine verilmesini istemek üzere sahsî bir talep hakkuna sahip olduğu ilave edilmektedir (INAN, Miras, s. 155-156; KÖPRÜUU, s. 172-173; GURSOY, s. 34-35; OOUZMAN, s. 17t; GÖNENSAYBIRSEN, s. 135). 
Roma Hukukunda, muayyen mal vasiyeti, vasiyet yapan kişiye ait bir ölïme bağlı tasarruftu ve vasiyet yapan kişi, bu tasarrufla, mirasçısı aleyhine olmak iłzere, bir kimseye belirli mallarını kazandırırdı. Gaius'a göre de, muayyen mal vasiyeti, "bir kimseye, mirasçı aleyhine, münferit şeyler kazandıran bir ölüme bağlı tasarruf" idi $^{50}$.

Roma Hukukunda, muayyen mal vasiyetinde, üç kişinin varlığı sözkonusu olurdu: Bunlar, vasiyetçi (testator, legator), kendisine muayyen mal vasiyetinin mükellefiyeti yüklenmiş olan mirasçı (heres, oneratus) ve vasiyetten yararlanan vasiyet alacaklısı (musaleh, legatarius, honoratus) idi ${ }^{51}$.

\section{B. Muayyen Mal Vasiyeti Çeşitleri \\ 1. Iustinianus'tan Önceki Durum}

Iustinianus'tan önceki dönemde, muayyen mal vasiyetlerinin uiçe aynıldığı görülmektedir. Bunlar, legatum, fideicommissum ve praelegatum'dur.

\section{a) Legatum}

Mirasçıya bir yükümlülük yüklemek anlamına gelen legare fiilinden türetilmiş ve XII Levha Kanunu'ndan itibaren mevcut olan legatum'lar, Ius Civile'ye göre sözkonusu olabilen mal vasiyetleriydi ${ }^{52}$.

Legatum, vasiyet içinde yapılan bir işlem olduğu için legatum'un geçerliliği, vasiyetin geçerliliğine bağlıydı. Eğger vasiyet, şekil şartlarına uyulmadan yapılır veya mirasçı nasbına ilişkin geçerli bir tasarrufu içermezse, legatum da vasiyetle birlikte geçersiz hale gelirdi ${ }^{53}$. Bu nedenle, vasiyet yapan kişinin vasiyet yapma ehliyetine (testamenti factio activa) sahip olması gerektiği gibi, legatum'dan yararlanacak olan kişinin de mirasçılık ehliyetine (testamenti factio passiva) sahip olması gerekirdi. Buna bağlı olarak, yabancılar, tüzel kişiler, dinsizler, müebbet cezalara veya ölüm cezasına mahkum edilenler, legatum'dan yararlanamazlardı.

50. DI MARZO, s. 570; KOSCHAKER-AYITER, s. 404; SCHULZ, s. 310.

51. SCHULZ, s. 312; UMUR, Miras, s. 174.

52. KOSCHAKER-AYITER, s. 404.

53. SCHULZ, s. 310. 


\section{aa) Çeşitleri}

Legatum'lar, yapılış şekillerine göre, çeşitlere aynlırdı. Bunlar, per vindicationem, per damnationem, sinendi modo ve per praeceptionem olmak üzere dört ayrı şekilde olabilirdi.

\section{aaa) Legatum Per Vindicationem}

Bu tip muayyen mal vasiyetinde, vasiyeti yapan kişi; lehine mal vasiyet ettiği kimseye, o malın mülkiyetini doğrudan doğruya kazandıracak bir ifadeyi vasiyetinde kullanırdı. Ömeğin, vasiyeti yapan kişi, miraş̧ı nasbına ilişkin tasarrufundan sonra, "Kölem Stichus'u Titius alsın, sahiplensin, ihraz etsin, onun olsun" (Gaius . 2. 193), şeklindeki bir ifadeyle, lehine mal vasiyet ettiği kişinin, vasiyet konusu malın mülkiyetini doğrudan dogruya kazanmasını sağlardı. Vasiyette mirasçı nasbedilen kişi, terekeyi iktisap eder etmez, lehine muayyen mal vasiyet edilen kişi de (honoratus) vasiyet konusu malın maliki olurdu. Zira, legatum per vindicationem, adından da anlaşıldığı gibi, "mửlkiyet vasiyeti" idi. Buna bağlı olarak, hak sahibi, malın 1 rei vindicatio (istihkak davası) ile talep edebilirdi" ${ }^{\text {s4 }}$.

Muayyen mal vasiyetine konu olan malın mülkiyetinin, lehine vasiyet yapılmış olan kişi tarafından, hangi anda iktisap edildiği konusunda, Klasik Dönem'de, Sabinianus'lar ile Proculianus'lar arasında fikir ayrilığı mevcuttu. Sabinianus'lara göre lehine muayyen mal vasiyet edilen kişi, her ne kadar, sözkonusu vasiyeti öğrendiğinde bunu reddedebilme ve iktisabın gerçekleşmemesini sağlayabilme imkanina sahipse de, vasiyeti ögrenmeden dahi vasiyet konusu malın mülkiyetini kazanmış olurdu. Proculianus']ara göre ise, bu kimse, vasiyet konusu malın mülkiyetini, vasiyeti ögrenip, bunu kabul ettigini bildirdikten sonra kazanırdi ${ }^{s s}$.

Bu çeşit vasiyetlerde, vasiyet yapan kişi, vasiyete konu olan mal gayrumislî bir malsa, hem vasiyeti yaparken hem de ölüm anında, Ius Civile gereğince bu malın maliki olmalıydı. Buna karşılı, vasiyete konu olan mal, misłî bir mal ise, vasiyeti yapan kişinin, sadece ölüm anında o malın maliki olması yeterliydi ${ }^{56}$.

54. HONIG, s. 416; BERGER, s. 541; KOSCHAKER-AYITER, s. 405; OG̈UZOǴLU, s. 315; BUCKLAND-MC NAIR, s. 130-131; SCHULZ, s. 316-317.

55. KOSCHAKER-AYITER, s. 407-408; DI MARZO, s. 572; BERGER, s. 541.

56. . DI MARZO, s. 572; UMUR, Miras, s. 175; SCHULZ, s. 317. 


\section{bbb) Legatum Per Damnationem}

Bu çeșit muayyen mal vasiyetinde, lehine mal vasiyet edilen kişi, malın mülkiyetini doğrudan doğruya kazanmamakta, sadece, mirasçıya karşı, malın kendisine teslimine yönelik bir alacak bakkına sahip olmaktayd. Burada, vasiyeti yapan kişi, vasiyet konusu malı, lehine mal yasiyet ettiği kişiye vermesi hususunda mirasçısına emir verirdi. Örneğin, vasiyette, miraş̧ı nasbına ilişkin tasarrufundan sonra, "Miraş̧ım, kölem Stichus'u Titius'a vermeye mecbur olsun, versin" (Gaius.2.201), şeklinde bir ifade kullanırd ${ }^{57}$.

Vasiyet yapan kişinin yaptığı bu tasarruf sonucunda, mirasçı ile lehine muayyen mal vasiyet edilen kişi arasında bir borç ilişkisi doğar (borç vasiyeti) ve bu da, borç doğuran kaynaklar arasında "akit benzerleri" grubuna dahil edilirdi ${ }^{58}$.

Lehine mal vasiyet edilen kişinin, vasiyet konusu malın mülkiyetini kazanabilmesi için, mirasçının, bu mülkiyeti, malın niteliğine göre, mancipatio, in iure cessio veya traditio işlemlerinden birisiyle, lehine mal vasiyet edilen kişiye devretmesi gerekirdi. Bu borcunu yerine getirmeyen mirasçıya karşı, actio ex testamento (vasiyetten doğan dava) açılır ve bu davanın sonucunda mirasçı, vasiyet konusu malın değerinin iki katına mahkum edilirdi ${ }^{59}$.

Legatum per damnationem ile, gerek vasiyeti yapan kişiye, gerek miraş̧ı nasbedilen kişiye ve gerekse üçüncü bir kişiye ait, halen mevcut veya henüz mevcut olmayan bir mahn vasiyet edilmesi mümkündü. Vasiyet konusu mal, bir üz̧üncü kişiye aitse, mirasç1, malın takdir edilen değerini vererek borcundan kurtulabilir$\mathrm{di}^{60}$.

\section{ccc) Legatum Sinendi Modo}

Bu çeşit muayyen mal vasiyeti, vasiyeti yapan kişinin, "Mirasçım, Lucius Titius'un, kölem Stichus'u almasına ve ona sahiplenmesine ses çıkarmamaya mahkum olsun", şeklindeki ifadesiyle yaplird1 (Gaius, 2. 209) ${ }^{6}$.

57. BERGER, s. 541; HONIG, s. 417; KOSCHAKER-AYITER, s. 405-406.

58. RADO, s. 176; UMUR, Roma, s. 387; KASER, s. 163.

59. BERGER, s. 541; DI MARZO, s. 572; SCHULZ, s. 317-318.

60. UMUR, Miras, s. 175; DI MARZO, s. 572. Lehine muayyen mal vasiyet edilen kişi için sadece bir alacak hakkının doğmasına neden olan legatum per damnationem, modern kanunlara örnek teşkil etmiş. TMK 464 vd'da da muayyen mal vasiyeti sonucunda sadece şahsî bir talep hakkının doğacağı kabul edilmiştir.

61. HONIG, s. 417-418; DI MARZO, s. 573; BERGER, s. 541. 
Burada da, per damnationem mal vasiyetinde olduğu gibi mirasçı ile lehine mal vasiyet edilen kişi arasında bir borç ilişkisi doğar, bu da borç kaynağı olarak akit benzerleri grubuna girerdi. Bu borcunu yerine getirmeyen mirasçıya karşı da actio ex testamento açılabilirdi. Ancak, bu muayyen mal vasiyeti çeşidinde, mirasçının borcu, vasiyet edilen malın mülkiyetini nakletmeye yönelik işlemlerden birisini yapmak değil, sadece o malın alınmasına tahammül ve müsaade etmekten ibaretti ${ }^{62}$.

Legatum sinendi modo ile, sadece vasiyette bulunan kişinin veya mirasçının mallan vasiyet edilebilir, fakat üçüncü bir kişiye ait mallar vasiyet edilemezdi. Bu nedenle, Gaius (7.210-211), bu tip mal vasiyetinin, konusu üçüncỉ kişiye ait bir mal da olabilen per damnationem mal vasiyetinden daha az imkanlar verdiğini, buna karşılık, sadece vasiyette bulunan kişiye ait bir mal üzerinde vasiyeti mümkün kilan per vindicationem mal vasiyetinden daha fazla imkanlar sağladığını belirtmektedir ${ }^{63}$.

\section{ddd) Legatum Per Praeceptionem}

Bu tip mal vasiyeti, "Lucius Titius, kölem Stichus'u' önceden (yani henüzz tereke taksim edilmeden) alsın", şeklinde bir ifade kullanılanarak yapılırdı (Gaius. 2.216) ${ }^{64}$.

Bu muayyen mal vasiyeti hakkında, Sabinianus'lar ile Proculianus'lar arasında görüş aynlı̆̆ı vardı. Sabinianus'lara göre, per praeceptionem mal vasiyeti ile, sadece nasbedilmis mirasçlardan birisine, tereke taksim edilmeden önce almak şartıyla, muayyen bir mal vasiyet edilebilir. Mirasçılar dışındaki bir yabancıya, bu yolla mal vasiyet etmek müinkün değildir. Proculainus'lar ise, mirasçılar dışında kalan bir üçüncü kişiye de, bu yolla mal vasiyet edilebileceğini ve bu çeşit mal vasiyetinin per vindicationem mal vasiyetinden farklı olmadığını ileri sürmekteydiler ${ }^{65}$.

\section{bb) Senatusconsultum Neronianum}

Vasiyeti yapan kişinin, muayyen mal vasiyeti yaparken malın kendisine, mirasçıya veya üçüncủ kişiye ait olmasına göre, legatum

62. UMUR, Miras, s. 175; HONIG, s. 418; DI MARZO, s. 573 .

63. DI MARZO, s. 573.

64. BERGER, s. 541 .

65. HONG, s. 418; DI MARZO, s. 573-574; UMUR, Miras, s. 175-176. 
şekillerinden birini kullanmak zorunda olması, uygulamada sakıncal sonuçlar doğuruyordu. Örneğin, vasiyeti yapan kişinin, mirasçlya ait bir malı per vindicationem vasiyet etmesi halinde, yapılan vasiyet geçersiz oluyordu. Bu sakıncayı ortadan kaldırabilmek amacıyla M.S. I.yy.'da senatusconsultum Neronianum çıkarılmıştır. Bu senatus karan, vasiyet edilen malın kime ait olduğuna ilişkin şekilciliği ortadan kaldırmış, vasiyeti yapan kişinin iradesini azami derecede dikkate almayı sağlamak amacıyla, başkasına ait olduğu için geçerli olmayan, örneğin per vindicationem bir mal vasiyetinin sanki per damnationem şeklinde yapıldığını farzederek, geçerli olacağını kabul etmiştir. O halde, bu karar, vasiyeti yapan kişinin sözlerinden çok, iradesini hakim k1lmaya yönelik bir yol izlemiştir ${ }^{66}$.

Klasik-Sonrasi Dönem'den sonra ise, bütün legatum'lar yukanda belirtilen dört şekilden birine bağlı kalmaksızın serbestçe yapılabilmeye başlanmıştur ${ }^{67}$.

\section{b) Fideicommissum}

\section{aa) Kavram}

İk İmparatorluk Dönemi'nde ortaya çıkan ve kısa zamanda geniş bir uygulama alanı bulan fideicommissum, legatum gibi oldukça sı kullanılan bir muayyen mal vasiyeti türï idi. Fideicommissum, murisin, mansup veya kanunî mirasçiya ya da muristen muayyen mal vasiyetiyle bir mal elde etmiş olan kişiye, ölümünden sonra bir arzusunu yerine getirmesi, örneğin üçüncui bir kişiye bir sey vermesi konusundaki bir ricasından ibaretti. Bu rica, hukukî bir bağa değil, kendisinden ricada bulunulan kişinin şeref ve dürüstlügüne dayandığ 1 için, işleme fideicommissum (fides'e, yani şeref ve dürüstlüge terkedilmiş) adı verilirdi. Bu nedenle, bu işlemden yarar sağlayacak olan üçüncü kişinin, fideicommissum'a dayanarak, kendisinden ricada bulunulan kişiye dava açma hakkı yoktu. Fideicommissum'un uygulaması artıp, bu işlemin temelini teşkil eden şeref ve dürüstlükk kurallarına uymayanların sayısının çoğaldığını gören Augustus, bu çeşit vasiyetlerin yerine getirilmelerini sağlamak için, cognitio extra ordinem usulü ile ileri sürülebilen bir persecutio fideicommissoria (fideicommissum davası) tanımıştır. Bu davalara, praetor fideicommissarius adı verilen özel praetor'lar bakarlardı.

66. BERGER, s. 698-699; DI MARZO, s. 574; HONIG, s. 418-419; KOSCHAKERAYITER, s. 409; SCHULZ, s. 318-319.

67. DI MARZO, s. 575-576; UMUR, Miras, s. 176; SCHULZ, s. 319. 
Böylece, fideicommissum, akit benzerleri grubuna giren bir borç kaynağ ${ }_{1}$ haline gelmişti ${ }^{68}$.

Fideicommissum ile, genellikle legatum şeklindeki mal vasiyetlerinden yararlanamayan kimselere, örneğin yabancılara mal vasiyet edilebilmekte, bunun yanında, legatum yükümlülüğü yüklenemeyen kimselere, örneğin kanunî mirasçılara veya bizzat muayyen mal vasiyetinden yararlanmış kimselere, bu yükümlülük yüklenebilmekteydi ${ }^{69}$.

Fideicommissum'un vasiyet yoluyla yapılması şart değildi. Vasiyetin ve legatum'un şeklî şartlar, fideicommissum için geçerli degildi. Yazll veya sözlï hiçbir şekle tâbi olmadan fideicommissum yapılabilirdi. Uygulamada, fideicommissum, çoğunlukla vasiyete ilave edilen ayrı bir mektupla (codicillum) yapılırdı. Buna karşılık, fideicommissum yapan kişinin, vasiyet yapma ehliyetine (testamenti factio activa) sahip olması gerekiyordu ${ }^{70}$.

Fideicommissum yapan kişi, mirasçının elde ettiği miktan aşmamak sartıyla, fideicommissum'un miktannı dilediği şekilde belirleyebilindi. Mirasçının elde ettiği miktar aşıldığı takdirde, fideicommissum, aşan kısım için hüiküimsüzdü ${ }^{71}$.

bb) Çeşitleri

aaa) Fideicommissum Universitatis (Genel Fideicommissum) ve Fideicommissum Specialis (Özel Fideicommissum)

Fideicommissum ile terekenin tamamı veya bir kısm, muayyen mal olarak vasiyet edilebilmekte idi.

Vasiyeti yapan kişi, mirasçısını nasbettikten sonra, terekenin tamamını, arzu ettiği, fakat hukuken mirasçısı haline getiremediği bir kimseye nakletmesini, mirasçı nasbettiği kişiden fideicommissum yoluyla rica edebilirdi. Klasik Sonrası Dönem'de, bu çeşit mal vasiyetlerine, fideicommissum universitatis (genel fideicommissum) adı verilmişti. Mirasçı, bütün terekeyi devir ve teslim ettikten sonra da mirasçılık sıfatını korur ve terekenin borçlarından sorumluluğu devam ederdi. Mirasçının, tereke borçlarından sorumluluğunun or-

\footnotetext{
"68. BERGER, s. 470-471; HONIG, s. 421; DI MARZO, s. 587; OGUZOĞLU, s. 317; SCHULZ, s. 312 .

69. UMUR, Miras, s.177; SCHULZ, s. 313 .

70. KOSCHAKER-AYTTER, s. 409-410; BERGER, s. 471; HONIG, s. 421 .

71. KOSCHAKER-AYTTER, s. 409-410; UMUR, Miras, s, 177.
} 
tadan kalkabilmesi için, bu borçlan stipulatio'larla, fideicommissum'dan yararlanan kişiye nakletmesi gerekirdi ${ }^{72}$.

Roma Hukukunda, bu genel nitelikteki fideicommissum'un yanında bir de, fideicommissum speciale adı verilen özel fideicommissum mevcuttu. Bu fideicommissum ile, terekeye ait münferit mallar, muayyen mal olarak vasiyet edilebilmekte idi. Burada önemli olan husus, devir yükümlülügüüün, sadece kanunî veya mansup mirasçıya değil, lehine muayyen mal vasiyetinde bulunulan kişiye de yüklenebilmesidir ${ }^{73}$. aria

bbb) Substitutio Fideicommissoria ve Fideicommissum Famili-

Daha önce de belirtildiği gibi Roma'da, infisahi şarta bağlı olarak mirasçı nasbedilemeyecegi gibi, muayyen mal vasiyeti de yapılamazdı. Mirasçı nasbedilen veya lehine muayyen mal vasiyet edilen kişinin, belli bir şart gerçekleştiğinde mirasçı olmaktan çıkmasına veya bu kişilerin ölümünde mirası belirli bir kişiye bırakmalarına ilişkin şartlar yok hükmündeydi. Roma Hukukundaki bu sakınca, substitutio fideicommissoria yoluyla, pratik olarak ortadan kaldırılmıştır. Buna göre, vasiyeti yapan kişi, mirasçının ölüimünden sonra, terekenin tamamının başka kimselere intikalini, $f$ deicommissum ile vasiyet edebilirdi. Gaius, bu çeşit fideicommissum'dan sözetmektedir: Cum Titius heres meus mortuus sit, volo hereditatem meam ad Maevium pertinere (Mirasçım Titius öldükten sonra, mirasımın Maevius'a intikal etmesini istiyorum). Vasiyeti yapan kişinin bu iradesini yerine getirmek için mirasçı, bizzat yaptı̆̆ı vasiyette, ya o kimseyi kendisine mirasçı gösterir ya da mirasçısına terekeyi o kimseye terketmesini bir fideicommissum'la bildirirdi. Bunlar yapılmasa da, ölen mirasçının mirasçıları, fideicommissum'un emrini yerine getirmek zorunda idiler. Bu şekilde, Roma'da gerçek anlamda bir mirasçının ikamesi ortaya çlkmaktadur ${ }^{74}$.

Substitutio fideicommissoria'dan sonra, Iustinianus'un 159 'uncu Novella ile son şeklini verdiği fideicommissum familiaria ortaya çımıştır. Fideicommissum familiaria işlemini yapan kişi, te-

72. KOSCHAKER-AYITER, s. 177; DI MARZO, s. 589; UMUR, Miras, s. 177.

73. DI MARZO, s. 591; UMUR, Mjras, s. 177.

74. KOSCHAKER-AYITER, s. 416; UMUR, Miras, s. 178; DI MARZO, s. 590-591. Fevkalade ikame, TMK 468 vd'da düzenlenmiş, mirasbırakanın mansup miraş̧ıya veya musalehe, kendikerinin ölümünden sonura veya muayyen bir müddetin sonunda, mirası veya vasiyet olunan muayyen malı ülçüncü şahsa nakletme yükümlüllügünü yükleyen bir işlem olarak hükme bağlanmıştr. 
rekenin tamamen veya kısmen, arka arkaya, aynı ailenin mensuplanna nakledilmesini sağlard. Böylece aile mameleki, bir bütün olarak, nesiller boyu, herhangi bir sınırlamaya tâbi olmadan, fideicommissum familiaria işlemini yapan kişinin iradesine uygun şekilde korunmuş olurdu. Iustinianus Döneminde, bu işlemin hükmünün dördünciü kuşaktan sonra sona ereceği kabul edilmiştir ${ }^{75}$.

\section{c) Praelegatum}

Roma Hukukunda, murisin bir tek mirasçısı varsa, bu tek mirasçıya yapılan muayyen mal vasiyetinin geçersiz olacağı, zaten mirasçılık sıfatıyla terekeyi kazandığı gerekçesiyle, kabul ediliyordu. Ancak, birlikte birkaç mirasçı varsa, aralarından bir tanesine yapılan muayyen mal vasiyeti geçerliydi ve buna praelegatum adı veriliyordu. Eger, muayyen mal vasiyetini yerine getirme yükümlülïğünün hangi mirasçıya düştügüu belirtilmemişse, mirasçılann tümü borçlanır ve her birisi, hissesi oranında vasiyeti yerine getirir$\mathrm{di}^{76}$.

\section{Iustinianus Dönemindeki Dunum}

Fideicommissum ile legatum arasındaki başlıca fark, fideicommissum'un, legatum'un şekilciliklerine ve sınırlamalanna tâbi olmaması idi. Zamanla, bir taraftan legatum'a ilişkin şekilcilik ortadan kalktığı, diğer taraftan legatum'a ilişkin sınırlamalar, fideicommissum'u da kapsayacak şekilde genişletildiği için, Iustinianus Hukukunda aralarında fark kalmamıştı. Bu dönemde, vasiyet içinde belirtilen muayyen mal vasiyetlerine legatum, müstakil codicillum'larda belirtilen muayyen mal vasiyetlerine ise fideicommis,sum denmekteydi ${ }^{77}$.

75. DI MARZO, s. 591; UMUR, Miras, s. 178. TMK 468/, 3. c.'ne göre, hukuk sistemimjzde fevkalade ikame, bir derece içinde sınırlandınlmuştır. Kanunun fevkalade ikameyi bir derece içinde sınılayan bu hükmü, emredici bir hukuk kuralı niteliğjindedir. Aynca, bu hịkǜm, MK 322/II'de dúzenlenen, aile vakıflannın daimî olarak aile fertlerine tahsis edilemeyeceği hạkkındaki kuralla da uyum içerisindedir (INAN, Aile Fideicomisi, s. 472; TUOR, s. 278; HATEMI, s. 300-301).

76. BERGER, s. 644; UMUR, Miras, s. 178-179; KOSCHAKER-AYITER, s. 404. Praelegatum, Türk hukukunda, "ön vasiyet" adını alarak kabul edilmiştir. Ancak, bu terimin yanlış seçildiği, "miraş̧ı lehine muayyen mal vasiyeti" deyiminin kullanılması gerektiği, doktrinde genel olarak kabul edilmektedir. Bu tür vasiyette, ayn kişi, hem mirasçıdır hem de lehine muayyen mal vasiyet edilen kişidir. Miraş̧ı hem mirası kabul hem de mal vasiyetinin ifasın talep edebilir. Ancak bunun aksi de mümkündür. Mirasçı, mirast redkettiği halde, vasiyet olonan malın kendisine verilmesini, MK 466/III gereğince isteyebilir (IMRE-ERMAN, s. 126; AYITER-KILIÇOGLU, s. 103; SEENER, s. 17; GURSOY, s. 162 vd.).

77. BERGER, s. 471; HONIG, s. 423; UMUR, Miras, s. 177; DI MARZO, s. 594. 


\section{Muayyen Mal Vasiyetlerinin Konusu}

Muayyen mal vasiyetlerine herhangi bir menfaat konu olabilirdi. Sadece mallar üzerinde değil, haklar üzerinde de muayyen mal vasiyeti yapllabilirdi.

Muayyen mal vasiyetleri, konularına göre isimlendirilirdi: Ferden (parça olarak) belirlenmiş bir malın vasiyetine "parça vasiyeti" (legatum speciei), nev'en (cinsiyle) belirlenmiş bir malın vasiyetine ise "cins vasiyeti" (legatum generis) adı verilirdi ${ }^{78}$.

Muayyen mal vasiyeti, "seçimlik vasiyet" şeklinde de yapılabilirdi. Seçimlik vasiyet durumunda, eğer per vindicationem bir mal vasiyeti sözkonusuysa seçim hakkı, lehine mal vasiyet edilen kişiye; per damnationem mal vasiyeti durumunda ise, vasiyette bulunan kişinin aksi yönde bir iradesi yoksa, seçim hakkı, mirasçıya yani borçluya aittî?

Belirli bir miktar paranın vasiyeti sözkonusu olabildiği gibi, yllık veya aylık bir gelirin vasiyet edilmesi de mümkündü. Bir gelirin vasiyet edilmesi sözkonusu olduğunda, bu gelir kaç aylık veya yıllık vasiyet edilmişse, o kadar sayıda birbirinden ayrı mal vasiyetinin bulunduğu kabul edilirdi ${ }^{80}$.

Bir irtifak hakkına veya cihaza yönelik muayyen mal vasiyeti de yapılabilirdi. Iustinianus Hukukunda, rehin hakkı da muayyen mal vasiyeti yoluyla tesis edilebilmeye başlanmıştır ${ }^{81}$.

78. DI MARZO, s. 579; UMUR, Miras, s. 176. Türk hukukunda da, muayyen mal vasiyetine konu teşkil eden malın niteliğine göre, parça vasiyeti- nev'i yasiyeti aynmı yapılmaktadır (İMRE-ERMAN, s. 124; KOCAYUSUFPAŞAOGLLU, s. 263; ŞENER, s. 19; GURSOY, s. 153-154).

79. DI MARZO, s. 579; UMUR, Miras, s. 176. Türk Hukukunda da seçimlik vasiyet yapmak mümkündür. Vasiyet yapan kişi, borçluya (vașiyeti ifa ile yükümlü kişiye) veya alacaklıya (lehine muayyen mal vasiyet edilen kişiye) bir seçim hakkı tanıyabilis. Seçim hakkınn kime ait olduğu ölüme bağlı tasarnufta belirtilmemişse, BK 71 gereğince bu hak borçluya ait olur. Vasiyet borçluss birden fazla ise, seçim hakkı bunların hepsine aittir, onlar bu hakkı birlikte kullanirlar (IMRE-ERMAN, s. 124125; KOCAYUSUFPASAOÁLU, s. 262-263; GURSOY, s. 184 vd.).

80. UMUR, Miras, s. 176. Türk Hukukunda da, MK $542 /$ 'de irat vasiyetinin yapılabileceł̧i hükme bağlanmıştır. MK 542/I, irat vasiyeli hakkında, Eşya Hukuku ve Borçłar Hukuku hükümlerine atıf yapmaktadır. Bu konuda, özellikle, kaydı hayatla irat hakkındaki BK 507 vd. hüikümlerinin uygulanması sözkonusu olur. Bu durumda, lehine muayyen mal vasiyet edilen kişi irat alacaklısı, bunu ifa ile yưikïmlïi olan mírasçı da irat borçlusudur (IMRE-ERMAN, s. 126; KOCAYUSUFPAŞAOGLU, s. 265; GÜRSOY, s. 155-156; OGUZMAN, s. 175).

81. UMUR-Miras, s. 176; ERDOGMUŞ, s. 28. Türk Hukukunda da, sınırlı aynî hak kurulmasının, muayyen mal vasiyetine konu olabileceği kabul edilmiştir. Örnę̆in, arzî bir irtifak hakkı, intifa hakkı, suikna hakkı, inşaat hakkı, kaynak hakkı, rehin hakkı, muayyen mal vasiyeti yoluyla, belirlj bir kimse lehine tesis olunabilir (IMRE-ERMAN, s. 127; KARAHASAN, s. 1149; KÖPRÜLÜ-KANETI, s. 297; GURSOY, s. 160 vd.; GONENSAY-BIRSEN, s. 134). 
Roma Hukukunda legatum debiti adı verilen "muayyen borc vasiyeti" kabul edilmişti. Legatum debiti ile, borçlu alacaklısına zaten mevcut olan borcunu vasiyet ederdi. Roma Hukukuna göre, bu durum, ancak alacaklıya bu işlemle bir fayda sağlanması halinde, ömeğin borçlunun muayyen mal vasiyetiyle, borca bağlı olan şart veya vadeden feragat etmesi halinde mümkündü. Alacaklıya fazladan bu çeşit bir fayda sağlaṃayan legatum debiti geçersizdi. ${ }^{82}$,

Diger taraftan alacaklar da muayyen mal vasiyetine konu olabilirdi. Alacaklar, muayyen mal vasiyetine iki şekilde konu olabilirdi. Öncelikle, bir kimsenin borçlusu oldugu alaçak, muayyen mal vasiyeti yoluyla, bizzat borçlunun kendisine vasiyet edilebilirdi ve buna legatum liberationis (alacağın ibrası vasiyeti) denirdi. İkinci olarak, bir kimse, sahip olduğu bir alacağı, muayyen mal vasiyeti yoluyla, bir üçüncü kişiye vasiyet edebilirdi ve buna da legatum nominis (alacak vasiyeti) adı verilirdi ${ }^{83}$.

Yukanda da belirtildiği gibi, Iustinianus Dönemi'ne kadar, sadece per damnationem yoluyla vasiyet edilebilen başkasına ait malların, Iustinianus Dönemi'nde, bütün muuayyen mal vasiyeti çeşitlerine konu teşkil edebileceği kabul edilmişti. Başkasına ait olan bir mal, muayyen mal vasiyeti yoluyla, bir kimseye vasiyet edilmişse, mirasçı, o malı iktisap ederek, lehine muayyen mal vasiyet edilen kişiye nakletmekle yükümlüydü. Eğer, sözkonusu vasiyet konusu malın maliki, o malı satmaz veya aşırı derecede yüksek bir fiyat talep ederse, yükümlülük altındaki mirasçı, malın değerini lehdara vermekle borcundan kurtulabilirdi. Aynı şekilde, vasiyet edilen mal mirasçının mülkiyetinde ise, mirasçı, malın mülkiyetini lehdara devretmekle yükümlüydiï ${ }^{84}$.

82. KOSCHAKER-AYITER, s. 413-414; DI MARZO, s. 580; SCHULZ, s. 318. Çă daş hukukumuzda ise, bu tilir bir sınırlama olmadan, muayyen borç vasiyetinin geçerli olduğu kabul edilmiştir. Çünkü, muayyen borç vasiyeti, alacaklıya, doğrudan doğruya bu işleme dayanarak, alacă̆ını dava edebilme hakkı verir. Mirasçanın borcu inkar etmesi halinde, alacaklının, eskj borcu sözkonusu etmesi ve onu ispat etmesi yükrümlülïigü yoktur. Aksine, muayyen borç vasiyetine dayanłlarak açılan davada, bu ispat kalfeti mirasçyya dijşer (KOSCHAKER-AYTTER, s. 414; GURSOY, s. 152).

83. BERGER, s. 540; DI MARZO, s. 580; IUSTINIANUS, Institutiones. 2. 20.21. Türk Hukukunda da, legatum liberationis ve legatum nominis, "ibra vasiyeti" ve "alacak vașiyeti" isimleri altında kabul edilmiștir (KOCAYUSUFPASAOGLU, s. 263-264; IMRE-ERMAN, s. 128; ŞENER, s. 2] ve 23).

84. KOSCHAKER-AYTTER, s. 406; DI MARZO, s. 578-579; SCHULZ, s. 318. Titrk Hukukunda, terekede bulunmayan bir maltn, lehine muayyen mal vasiyet edilen kişiye tedarik edilmesine iliş̧in mal vasiyetine "tedarik etme vasiyeti" adi verilmektedir. MK 464/3.c.'ye göre, terekede bulunmayan bir malın vasjyet edilmesi halinde, murisin tasarnufundan aksi antaşılmadıkça, vasiyeti ifa etmekle yükümlí olan kişi, 


\section{Vasiyet Edilen Muayyen Malın Kazanılması}

Vasiyette konu olan muayyen mal, ancak vasiyeti yapan kişi öldükten sonra, lehine muayyen mal vasiyet edilen kişinin hayatta olması şartıyla kazanılabilirdi ${ }^{85}$.

Romalılar, bu konuda iki farklı durumu birbirinden ayırırlardı. Bunların birincisi, lehine muayyen mal vasiyet edilmiş kimsenin vasiyete hak kazandığı an olan dies cedens, ikincisi ise, bu hakkını ileri sürerek talepte bulunabileceği an olan dies veniens idi.

Dies cedens, kura! olarak, vasiyeti yapan kişinin ölümü anı idi. Sonralan bazı kanunlar, bu anı vasiyetin açılması anı olarak tespit etmişlerse de, Iustinianus Dönemi'nde, yine murisin ölümü anının esas alındığı görülmektedir. Eğer muayyen mal vasiyeti, geciktirici şarta bağlı olarak yapılmışsa, dies cedens, şartın yerine gelmesiyle gerçekleşirdi. Dies cedens anından itibaren, her ne kadar, musaleh henüz vasiyet konusu hakkı kazanmamışsa da, bir beklemece (muntazar) hak elde etmiş durumdaydı. Buna bağh olarak, musaleh, dies cedens anından sonra ve fakat vasiyet konusu mah elde etmeden önce ölecek olursa bu beklemece hak mirasçılarına geçer ve onlar, vasiyet edilen malı elde edebilirlerdi ${ }^{86}$.

Dies'veniens ise, lehine muayyen mal vasiyet edilen kişinin, vasiyet konusu malı talep edebilir hale geldiği andır. Mansup mirasçının mirası kabul işlemini (aditio) yapmasıyla, dies veniens, yani vasiyet konusu malın lehine muayyen mal vasiyet edilen kişi tarafından talep edilebileceği durum ortaya çıkardı. Lehine muayyen mal vasiyet edilen kişi, mansup mirasçının mirası kabul etmesiyle, yani dies veniens'in gelmesiyle, vasiyetin türüne göre, ya vasiyet konusu malın mülkiyetine (legatum per vindicationem) ya da

vasiyeti ifa borcundan kurtulur. Bunun aksini ispat etme ylikü, musalehe düşer. Bu ispat bazı hallerde kolay olur. Ömę̆gin, vasiyețe bulunan kişi, vasiyet ettiğ malın terekede bulunmadığını bile bile vasiyet etmişse, murisin iradesinin, bu malın mirascı tarafından tedarik edilerek musalehe verilmesi yönünde olduğu sonucuna kolaylukla varılabilir. (IMRE-ERMAN, s. 129; KOCAYUSUFPAŞAOĞLU, s. 265-266: ESCHER, s. 227: GÜRSOY, s. 157 vd; BELGESAY, s. 52; GÖNENSAY BIRSEN, S. 133-134).

85. KOSCHAKER-AYITER, s. 412; DI MARZO, s. 580-581; UMUR, Miras, s. 179 Türk hukukunda da, MK 523 gere zince, lehine muayyen mal vasiyet edilen kişinin bu vasiyetten yararlanabilmesinin ana koşulu, murisin oltimü anında hayatta olmasıdır. Bu nedenle, musaleh vasiyetçiden önce ölmüşse, vasiyet olunan mal, ölüme bă lı tasarnuftan aksi anlaşılmadıkça terekeye aittir.

86. BERGER, s. 435; UMUR, Miras, s. 179; SCHULZ, s. 324. 
kendisine olan borcun yerine getirilmesine ilişkin şahsî bir talep hakkına (legatum per damnationem veya fideicommissum) sahip olurdu. Bunun için de, lehine muayyen mal vasiyet edilen kişinin hiçbir özel işlem veya kabul işlemi yapmasına gerek yoktu. Ancak, lehine muayyen mal vasiyet edilen kişi, dava açmamakla veya yükümlülük altında olan kişiyle bir ibra anlaşması yapmakla mụayyen mal vasiyetini reddedebilirdi ${ }^{87}$.

\section{E. Muayyen Mal Vasiyetlerinin Simırlan}

Roma'da genellikle herkes vasiyet yapardı. O dönemin örfâdetlerine göre, bir kimsenin vasiyetinde bütün dostlarını hatırlaması ve her birine bir şeyler bırakması gerekirdi. Bu nedenle yapılan vasiyetlerde çok sayıda muayyen mal vasiyetleri bulunur, hatta bazı durumlarda mirasçı, terekeden hiçbir şey elde etmeyecek şekilde, sadece mirasçılık sıfatını kazanırdı. Romalılar, bugünkü düşüncenin aksine, terekeden maddî bir malın kazanılması ile murisin sahsiyetine halef olmayı birbirinden ayırırlar ve terekeden hiçbir şey elde edilmese dahi, şahsiyete halef olmayı bir şeref kazanma yolu olarak kabul ederlerdi ${ }^{88}$.

Fakat, muayyen mal vasiyetlerinden böyle aşurı şekilde faydalanma, bazı durumlarda, miraş̧ı olmakta hiçbir menfaati kalmayan mirasçının mirası reddetmesine sebep olmakta ve buna bağlı olarak, terekenin mirasçısı kalmadığından, vasiyetle birlikte muayyen mal vasiyetleri de ortadan kalkmaktaydı. Bu duruma engel olmak ve özellikle muayyen mal vasiyetlerinin geçerli kalabilmelerini sağlamak amacryla, Cumhuriyet Dönemi'nde, Lex Furia testamentaria

87. BERGER, s. 435; UMUR, Miras, s. 180; KOSCHAKER-AYITER, s. 413; DI MARZO, s. 582; SCHULZ, s. 324-325. Türk hukukunda, lehine muayyen mal vasiyet edilen kişi, kanunî veya mansup mirasçılann aksine, vasiyet konusu malı, kanun hilkmil geregince (MK 539), kendilizinden iktisap edemez. Musaleh, sadece, MK 541/l.c.'ye göre, vasiyeti ifa ile yükümlä olan vassa o kişiye karşı, yoksa kanunî veya mansup mirasçılara karşı, şahsî bir talep hakkına sahip olur. MK 541/2c.'ye göre, vasiyet borcu, kanunî veya mansup mirasçıntn mirası kabul ettiği veya reddetme hakkuntn düştilga anda muaccel olur. Vasiyet borcu muaccel olduktan sonra, musaleh, vasjyet borçlusundan vasiyetin yerine getirilmesini talep etme ve but talep yerine getirilmediği takdirde dava açma hakkına sahip olur (MK 541/3.c.). Bu kuralın istisnasına MK 542/I'de rastlanmaktadır. Buna göre, vasiyet konusu şey, murisin kendi blämüne karşı akdettił̆i bir sigortanın bedelí ise, lehine vasiyet yapılan kimse, hakkm doğndan doğnuya sigortacidan talep edebilir (INAN, Miras, s. 159; GÜRSOY, s. $70 \mathrm{vd}$.).

88. KOSCHAKER-AYITER, s. 415; UMUR, Miras, s. 180; DI MARZO, s. 582; HONIG, s. 423. 
ve Lex Voconia adında iki kanun çıkanlmıştı ${ }^{89}$. Bu kanunlarla, muayyen mal vasiyetlerine konu olan miktarlar sınırlandırılmak istenmiştir. Lex Furia testamentaria, muayyen mal vasiyetlerinin 1000 as'1 aşamayacağı, Lex Voconia ise, hiçbir muayyen mal vasiyetinin, mirasçı tarafindan elde edilen menfaatten daha fazla olamayacağı hükümlerini getirmiştir. Fakat, bu tedbirler yeterli olmamıştır. Zira, vasiyet yapan kişi 1000 as'llk sınırın altında kalarak çok sayıda muayyen mal vasiyeti yapabilmekte, aynı şekilde, bu vasiyetlerin miktarı artıkça mirasçının hissesi de azalmaktaydı ${ }^{90}$.

Bunun üzerine M.Ö. 40 yılında Lex Falcidia adında bir kanun çıkanlmış ve bu kanunla, muayyen mal vasiyetlerine ilişkin eski stnırlamalar kaldırılarak, terekenin en az 1/4'ünün mirasçılara kalmas1 gerektiği hükmü getirilmiştir ${ }^{91}$. Lex Falcidia'nın hükümleri, aslen sadece legatum' lar hakkında geçerliydi. Ancak, M.S. 1. yy.'In ortalarnda çikarılan senatusconsultum Pegasianum ile, bu hükmün $f i$ deicommissum'lara da uygulanacağı kabul edilmiştir ${ }^{92}$. Bu yeni düzenlemeye göre, eğer muayyen mal vasiyetleri terekenin 3/4'ünüi aşıyorsa, o orana inecek şekilde ipso iure tenkis edilirlerdi. Iustinianus, Lex Falcidia'nun bu emredici hükmünü bir yorum hükmü (ius dispositivum) haline getirdi ve murisin, bu hükümlerin uygulanmasına vasiyetinde engel olabileceğini kabul etti ${ }^{33}$.

Günümüz hukukunda olduğu gibi, Roma Hukukunda da muayyen mal vasiyetine konu olan şeyin hukuka veya ahlaka aykırı bir şeyin yapilmasına ilişkin olması halinde, muayyen mal vasiyeti geçersizdi ${ }^{94}$.

89. BERGER, s. 552-561; HONIG; s. 424.

90. HONIG, s. 424; DI MARZO, s. 582.

91. BERGER, s. 552; KOSCHAKER-AYITER, s. 415; SCHULZ, s. 327.

92. BERGER, s. 699; DI MARZO, s. 583; SCHULZ, s. 328.

93. KOSCHAKER-AYTTER, s. 416; UMUR, Miras, s. 180; SCHULZ, s. 329. Türk Hukukunda da murise, oliime bağlı tasarruf yapma iktidar ve yetkisi seklinde tanımlanan, vasiyet serbestisi tanınmiştır. Ancak, vasiyet serbestisine getirilen en önemli sinırlama, murisin yakın hısımlanna tanınan mahfuz hisse hakkıdır. Mahfuz hisseyi oluşturan miktar üzerinde, muris tasarruf edemez. Mahfuz hisse, kural olarak, kanunî mirasçılara kajmak zorundadır. MK 452'de mahfuz hisseli mirasçtlar sayılmıs, MK 453'te ise, mahfuz hisse oranlan belirlenmiştir.

94. DI MARZO, s. 586-587. Ömeğin, bir miktar paranın ahlaka aykın kitaplar yayım, genelev kunulması, uyuşturucu madde imalatı gibi bir amaca tahsis edilmesine yönelik ölüme bał̧ tasarufların bizatihi kendisi hukuka veya ahlaka aykurodır ve bu nedenle iptal edilebilir. Ölïme bağlı tasarnuflarda yer alan ફart veya mükellefiyetler de hukuka veya ahlaka aykm ise, tasarruf iptal edilebilir (INAN, Miras, s. 200-201). 


\section{SONUÇ}

Hukuk düzeni tarafından hak sahibi süje, yani kişi olarak kabul edilen bir insan öldüğ̈ünde, bu kişinin sahip olduğu haklann, malvarlığının ve diğer iliş̧kilerinin ne olacağı sorunu, her toplumun ekonomik, sosyal, siyasi, ahlaki ve dini düş̧ünce ve inanctna uygun olarak, özel mülkiyet kavramına da verilen öneme göre, farklı şekillerde çözüme bağlanmışır.

Roma Hukuku'nun ilk dönemlerinde öncelik taşıyan mirasçıllğın kanuni miraş̧ılık olduğu, ancak vasiyet yapmanın yaygınlaştığı sonraki dönemlerde, kanuni mirasçılığın vasiyete dayanan mirasçılığın gerisinde kalarak ailenin halefini belirleme hakkının hukuk düzenine değil, aile babasına düssen bir hak ve görev olarak kabul edildiği görülmektedir. Buna bağlı olarak, Roma Hukuku'nda, vasiyetin büyük bir uygulama alanına sahip olan bir ölüme bağlı tasarruf olduğu ve murisin ölümünden sonra malvarlı̆̆mın ne olacağı hususundaki isteklerinin mutlak bir nitelik taşıdığı söylenebilir. Ancak, Cumhuriyet Dönemi'nde, murisin bu mutlak hakkını çeşitli sınırlamalara tâbi tutma eğiliminin ortaya çıktığı ve nihayet lustinianus Dönemi'nde bazı mirasçılann pars legitima adı verilen mahfuz hisseye sahip olmaya başladıkları da gözardı edilmemelidir.

Muris son isteklerini yaptığı vasiyet içerisindeki tasarruflarla, yani mirasçı nasbı başta olmak üzere, karısı ve çocuklan için vasi tayinleri, köle azad etmeleri ve özellikle konumuzu ilgilendirmesi bakımından muayyen mal vasiyetleri şeklinde dile getirirdi. Roma'da, herkesin vasiyetinde dostların ı hatılayıp ona bir şeyler bırakması gerektiği şeklindeki düşünceye bağlı olarak oldukça geniş bir uygulama alanına kavuşan muayyen mal vasiyetleri, Roma Miras Hukuku'nun en önemli konularında birini oluşturmuştur.

Bu çalışmadan da anlaşılacağı gibi, muayyen mal vasiyetine ilişkin kurallar açısından Roma Hukuku ile Türk Medeni Kanunu karşılaşııııldı ı̆ında aralarında çok büyük benzerlikler bulunduğu ve bu konuda Türk Medeni Kanunu'nun, İsviçre Medeni Kanunu'na bağlı olarak, Roma Hukuku'ndaki vasiyete dayanan mirasçılığa ve muayyen mal vasiyetine ilişkin kurallardan büyük ölçüde etkilendigi sonucuna kolaylikla varılabilir. 


\section{BIBBLIYOGRAFYA}

AYITER, Kudret: Roma Hukuku Dersleri, Aile Hukuku, Íkinci Bası, Ankara 1963.

AYITER, Nuşin-KILIÇOĞLU, Ahmet: Miras Hukuku, Ankara 1989.

BELGESAY, Mustafa Reşit: Türk Kanunu Medenisi Şerhi, Miras, Űçüncia Kitap, Dördünciu Baskı, tstanbul 1952.

BERGER, Adolf: Encyclopedic Dictionary of Roman Law, Philadelphia 1953.

BERK1, Şakir: Roma Hukuku, Ankara 1949 (Roma).

Romada Miras hukuku, AÜHFD, 1953, C.10, S.1-4, s. 542-570 (Roma Miras).

Miras Hukuku, Ankara 1975 (Miras).

BUCKLAND, W. Warvick-MC NAIR, Arnold: Roman Law and Common Law, A Comparison in Outline, Cambridge 1936.

ÇAĞA, Tahir: Tỉrk Isviçre Hukukuna Göre Mahfuz Hisseli Miraş̧larnn Hukukî Vaziyeti, tstanbul 1950.

DI MARZO, Sałvatore (Çev: UMUR, Ziya): Roma Hukuku, Ikinci Baskı, Istanbul 1959.

ERDOǦMUŞ, Belgin: Roma Eşya Hukuku, İstanbul 1989.

ESCHER, Arnold (Çev: ANSAY, S. Şakir): Medeni Kanun Şerhi, Miras Hukuku, Ankara 1953.

GÖNENSAY, Samim-BIRSEN, Kemalettin: Miras Hukuku, İkinci Bası, istanbul 1963.

GÚNAL, A.Nadi: Roma Miras Hukukuna Genel Bir Bakış ve Vasiyet Yolu ile Miras, AÜHFD, 1995, C.44, S.1-4, s.425-442.

GÜRSOY, K. Tahir: Türk Medeni Kanunu Hükủmlerine Göre Mal Vasiyeti, Ankara 1955.

HATEMl, Hüseyin: Önceki ve Bugïnkü Türk Hukukunda Vakıf Kurma Muamelesi, İstanbul 1969.

HONIG, Richard (Çev: TALIIP, Şemsettin): Roma Hukuku, Istanbul 1938.

IMRE, Zahit-ERMAN, Hasan: Miras Hukuku, Istanbul 1989.

INAN, Ali Naim: Aile Fideicomisi, Türk hukuk Ansiklopedisi, Ankara 1962, s. 471-472.

Miras hukuku, tkinci Bası, Ankara 1982 (Miras). 
IUSTINIANUS (Çev: UMUR, Ziya): Institutiones, Itstanbul 1968.

KARADENIZ-ÇELEBICAN, Özcan: Roma Hukuku, Tarihî Giriş-Kaynaklar-Genel Kavramlar- Şahsın Hukuku- HakJarnn Korunması, Ankara 1997.

KaRAHASAN, M. Reşit: Türk Medeni Kanunu, Eşya Hukuku, iki Cilt, Ankara 1977.

KASER, Max (Çev: DANNENBRING, Rolf): Roman Private Law, Durban 1965.

KOCAYUSUFPAŞAOĞLU, Necip: Miras Hukuku, Ikinci Bası, İstanbul 1978.

KOSCHAKER, Paul-AYITER, Kudret: Modern Özel Hukuka Giriş Olarak Roma Öze! Hukukunun Ana Hatlan, Yedinci Bast, Izmir 1993.

KÖPRÜLUU, Bülent: Miras Hukuku Dersleri, Genişletilmiş ve Yenilenmiş likinci Bası, İstanbul 1985 .

KÖPRÜLÜ, Bülent-KANETi, Selim: Sınırlı Aynî Haklar, Genişletilmiş ve Yenilenmiş Ikinci Bası, İstanbul 1982-1983.

MUIRHEAD, J. Spencer: An Outline of Roman Law, Edinburgh 1947.

OĞUZMAN, Kemal: Miras Hukuku, Ợüncỉ Bası, Istanbul 1984.

Ő̌UZOð̌LU, Cahit: Roma Hukuku, Ankara 1959.

ÖZTRAK, Ilhan: Miras Hukuku, Giriş-Kanundan Doğan Miraş̧̨llk-Ölüme Băglı Tasarruflar, Ankara 1968.

RADO, Tưrkan: Roma Hukuku Dersleri, Borçlar Hukuku, Istanbul 1983.

SCHULZ, Fritz: Classical Roman Law, Oxford 1950.

ŞENER, Esat: Miraş̧ı Nasbı ve Muayyen Mal Vasiyeti, AD., 1976, C.67, S.1-2, s. 7-32.

TUOR, Pierre (Çev: ARTUS, Amil): İsviçre Medeni Kanununun Federal Mahkeme İçtihatlarna Göre Sistemli Izahı, Ankara 1956.

UMUR, Ziya: Roma Miras hukukunun Ana Hatlan, IÜHFD, 1966, C.31, s. 159-195. (Miras).

Roma Hukuku Eşya Hukuku (Aynî Haklar), Istanbul 1983 (Eşya).

Roma Hukuku Ders Notlan, Istanbul 1987 (Roma).

Roma Hukuku Lügatu, Istanbul 1983 (Lügat). 